\title{
Pediatric Patients and Pain
}

\author{
Pistulli E ${ }^{1}$, Krasniqi $F^{2}$, Neçaj L ${ }^{1}$ \\ ${ }^{1}$ Faculty of Technical Medical Sciences, University of Medicine in Tirana, Albania \\ ${ }^{2}$ Neonatology Department, University Hospital Center, Prishtina-Kosovo \\ epistulli@yahoo.com
}

Abstract: Pain is an important part of the disease; it's the first evident symptom. Recently it is not considered anymore by the researchers and the doctors as a symptom, but as a specific disease, defined as "The Fifth Vital Sign".

Pain assessment is an essential element for the treatment. The success of a good analgesic management is based firstly in the valuation of the pain according to the scales.

The Faces pain scale is used for children 4-7 years old, while the Visual analog Scale(VAS) is used for children above this age.

A study from December 1, 2011 to May 31, 2012, was used to assess the acute pain levels among 177 children from birth to 13 years old in Obstetrics and Gynecology Hospital, an University Hospital Centre, a Pediatric Hospital and an Outpatient Services in Tirana. For patients incapable to verbalize the pain intensity in a reliable way (neonates to the age of four years old), the hetero-evaluation was used. The hetero-evaluation is realized only with one assessment scale, while patients older than 4 years and younger than 6 years old were assessed using the hetero-evaluation and auto-evaluation scale according to the Faces Scale and VAS.

The assessment according to VAS is applied in two positions, horizontally and vertically. The results obtained from the different scales and the VAS positions are compared. The NFCS and the Faces Scale are much more easily accessible by the nursing staff; while the multidimensional scales (OPS, CRIES, PIPP) were found more difficult to be used.

Keywords: pediatric patients; pain treatment; visual analogue scale. INTRODUCTION

The medical science is becoming more and more sophisticated, but unfortunately there is more to do with the pain management. Adults are the first persons that benefited from the recent researches in this direction, mainly in the last two decades; meanwhile "uncommonly", the pain is still untreated or insufficiently untreated among the children. ${ }^{[5][13][38]}$

Physical pain is not just a transmission of electrical impulses in the correspondly sectors; it's considered as a "conflict" between the stimulant and the person that is suffering. ${ }^{[1][3][44]}$ Unrelieved pain may cause anxiety and stress, or in other cases even psychological and behavioral long term consequences. ${ }^{[26]}$

Pain is an important part of the disease; it's the first evident symptom. ${ }^{[4][41]}$ Recently it is not considered anymore by the researchers and the doctors as a symptom, but as a specific disease, defined as "The Fifth Vital Sign". Synchronal with this reconception, there are other new notions like nervous system hypersensitivity caused by the acute pain and the rehabilitation, known for their important role due to major developments in the multimodal analgesia.

www.arjonline.org

Page 25 
Last years the researches are mostly focused on pain assessments as the main element that precedes the treatment. ${ }^{\left[{ }^{48]}\right.}$ There is used a specific number of assessments scales to measure the pain, mainly for the acute pain; but none of them fulfill at the same the criteria of validity, reliability and applicability. Anyways, we can say that there are adopted some assessment scales according the researches or for daily use only.

Pain assessment is an essential element for the treatment. The success of a good analgesic management is based firstly in the valuation of the pain according to the scales. ${ }^{[2][48]}$

Schematically, we can say that we use the behavioral scale like NFCS or CHEOPS or multidimensional scales (that combine the physiological markers like Pam or $\mathrm{SpO}_{2}$ with the behavioral variations) like OPS, PIPP, CRIES, etc. to diagnose the children. ${ }^{[19][21]}$

Pain assessment is based in two groups of measurement: the measurement of physiological parameters ${ }^{[26]}$ and the measurement of behavioral factors. ${ }^{[11]}{ }^{[18]}$ The physiological factors (like tachycardia, tachypnea, sweating, and the increase of arterial pressure) are always part of the pain, but they are not specific. Therefore, the behavioral scales are the main modalities used to assess the pain in neonates, infants and children under 4 years old that are not capable of verbal communication. ${ }^{[12]}$ These scales are based on facial expressions (crying or grimace), motor response, the vision and verbal response; for example the FLACC scale.

Although there is a considerable number of pain assessment scales, only some of them could be used for practical intention. We can use the FLACC scale for abovementioned age-group. The Faces Pain Scale is used for children 4 to 6-7 years old, while the Visual Analog Scale (VAS) is used for children above this age. ${ }^{[14][17][46]}$

\section{PURPose OF THE STUDY}

To recognize the physiopathological mechanisms behind the pain and these assessment and treatment methods applied to pediatric patients in order to compile the diagnosis and medical intervention, increasing in this way the treatment effectiveness.

\section{THE ОВJECTIVES}

1. To describe the pain characteristics of the pediatric patient and its physiological consequences to the body.

2. To describe the criteria of pain assessment scale selection according to the children age and pain type.

3. To know more about using pharmaceuticals and non pharmaceuticals methods in treating pain.

\section{MATERIALS AND METHOdS}

A 7-months study from December 1, 2011 to May 31, 2012, was used to assess the acute pain among 177 children from birth to 13 years old in Obstetrics and Gynecology Hospital, University Hospital Centre, Pediatric Hospital and Outpatient Services in Tirana.

For patients, incapable to verbalize the pain intensity in a reliable way (neonates to <4years old), it is used the hetero-evaluation. The hetero-evaluation is realized only with one assessment scale.

While patients $\geq 4$ years old and $<6$ years old are assessed using the hereto-evaluation and auto-evaluation scale according to the Faces Scale and VAS.

The auto-evaluation of the acute pain intensity is applied according to two different assessment scales, consisting in the same procedure, on the same patients. The assessment according to VAS is applied in two positions, horizontally and vertically. The results obtained from the different scales and the VAS positions are compared between one another. 
Pediatric Patients and Pain

The auto-evaluation scales are combined as below:

- VAS/ NRS

- VAS/ Faces Scale

Pain is divided in 4 different levels, for all the scales:

\begin{tabular}{|c|c|c|c|c|c|c|c|c|c|}
\hline \multirow{2}{*}{\multicolumn{2}{|c|}{ LEVELS }} & NFCS & CRIES & OPS & NRS & VAS & $\begin{array}{l}\text { Faces } \\
\text { Scale }\end{array}$ & CHEOPS & PIPP \\
\hline & & $0-10$ & $0-10$ & $0-10$ & $0-10$ & $0-10$ & $0-10$ & $4-13$ & $0-21$ \\
\hline 1 & Mild Pain & \multicolumn{5}{|c|}{$0-<3$} & 2 & $4-<7$ & $0-<7$ \\
\hline 2 & $\begin{array}{c}\text { Moderate } \\
\text { Pain }\end{array}$ & \multicolumn{5}{|c|}{$\geq 3-<5$} & 4 & $\geq 7-<9$ & $\geq 7-<11$ \\
\hline 3 & Intense Pain & \multicolumn{5}{|c|}{$\geq 5-<7$} & 6 & $\geq 9-<11$ & $\geq 11-<17$ \\
\hline 4 & $\begin{array}{c}\text { Maximum } \\
\text { Pain }\end{array}$ & \multicolumn{5}{|c|}{$\geq 7-10$} & 8 ose 10 & $\geq 11-13$ & $\geq 17-21$ \\
\hline \multicolumn{2}{|c|}{$\begin{array}{c}\text { Therapeutic } \\
\text { Intervention } \\
\text { Threshold }\end{array}$} & \multicolumn{5}{|c|}{$3 / 10$} & $4 / 10$ & $9 / 13$ & $11 / 21$ \\
\hline
\end{tabular}

According to Consensus Conference "Évaluation et Stratégies de Prise en Charge de la DouleurAiguë chez l'Enfant de 1 Mois à 15 Ans", ANAES, March 2000.

The population taken in consideration for the study is divided in 4 age-groups according to the suitable usage of the assessment scales, and it is represented in the table below.

\begin{tabular}{|c|c|c|c|c|c|}
\hline \multirow{2}{*}{\multicolumn{2}{|c|}{ AGE GROUP }} & \multicolumn{2}{|c|}{ HETERO-EVALUATION } & \multicolumn{2}{|c|}{ AUTO-EVALUATION } \\
\hline & & & Non & & Non \\
\hline I & 0 to $<1$ month & CRIES & $\begin{array}{l}\text { NFCS } \\
\text { PIPP }\end{array}$ & & \\
\hline II & $\begin{array}{l}\quad \geq 1 \text { month } \\
\text { to }<4 \text { years old }\end{array}$ & $\begin{array}{c}\text { OPS } \\
\text { CRIES }\end{array}$ & CHEOPS & & \\
\hline III & $\begin{array}{l}\geq 4 \text { years old to } \\
\quad<6 \text { years old }\end{array}$ & OPS & CHEOPS & $\begin{array}{c}\text { VAS } \\
\text { Faces Scale }\end{array}$ & $\begin{array}{c}\text { VAS } \\
\text { Faces Scale }\end{array}$ \\
\hline IV & $\geq 6$ years old & & & $\begin{array}{l}\text { VAS } \\
\text { NRS }\end{array}$ & $\begin{array}{l}\text { VAS } \\
\text { NRS }\end{array}$ \\
\hline
\end{tabular}

American Research Journal of Pediatrics

Page 27 


\section{Pediatric Patients and Pain}

The assessment is applied among 177 patients, $40.1 \%$ of them females and $59.9 \%$ males.

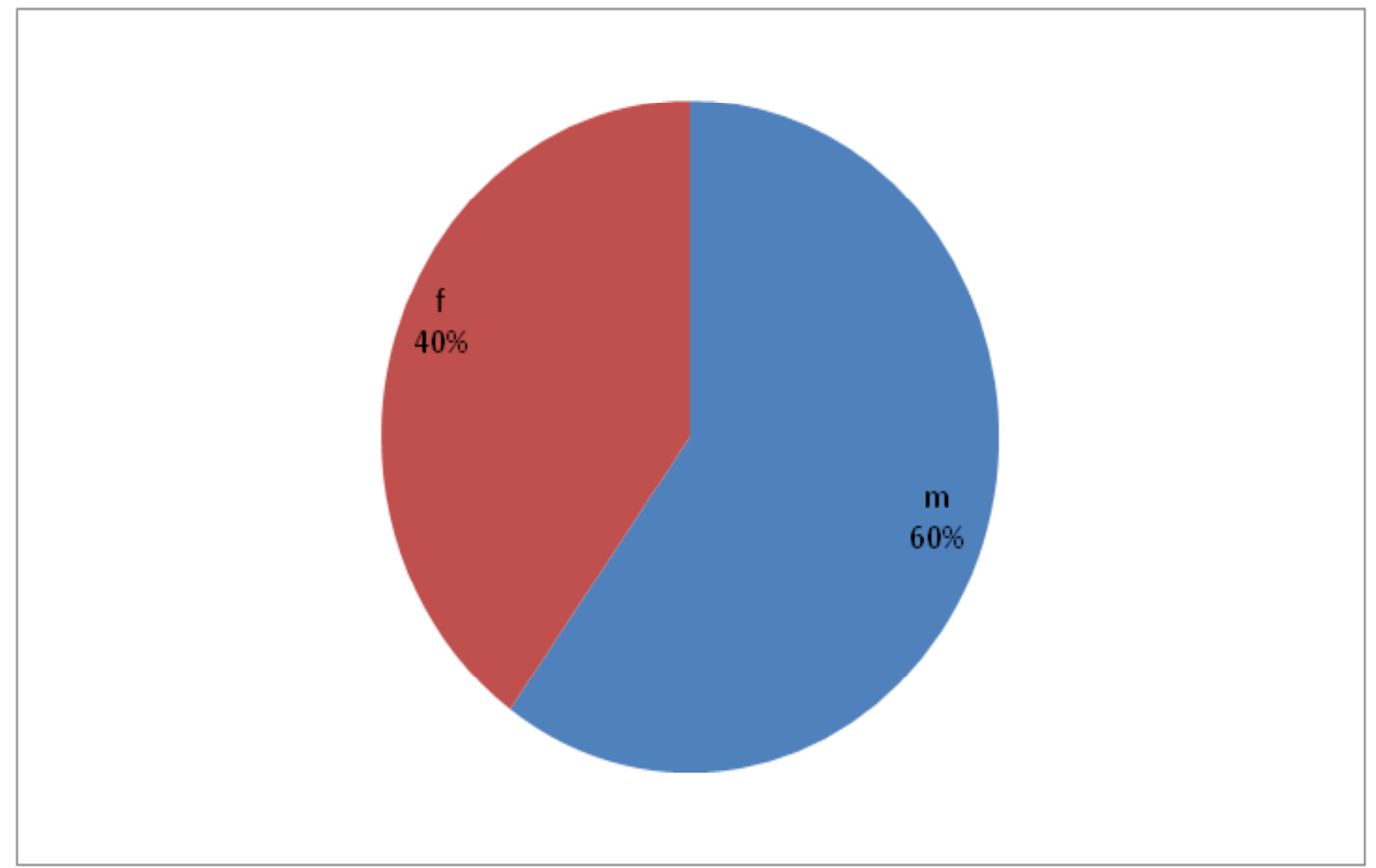

The division according to the type of pain (postoperative/acute non postoperative) is represented below:

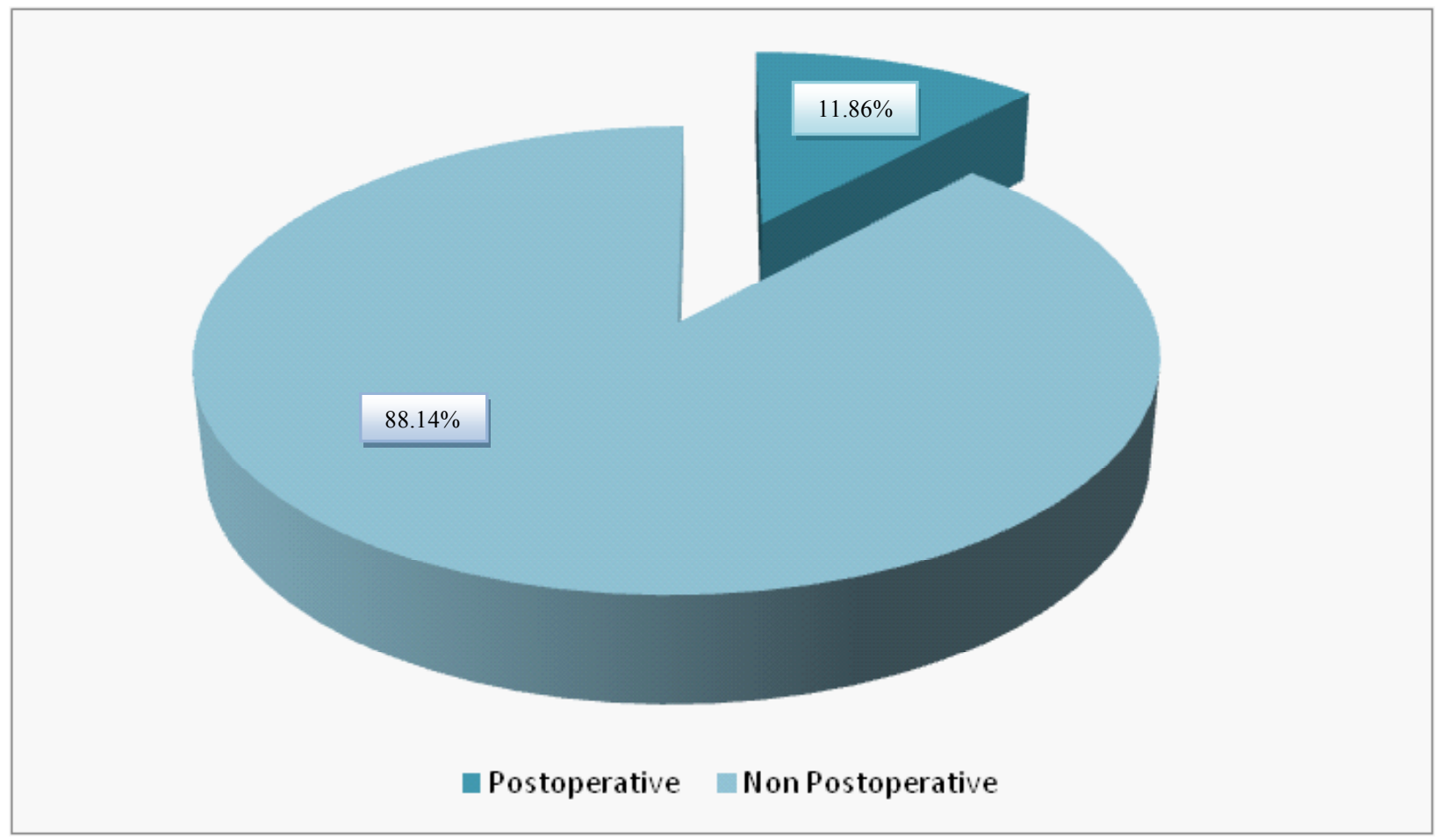


Pediatric Patients and Pain

The patients are distributed as below according to the pain type and the gender:

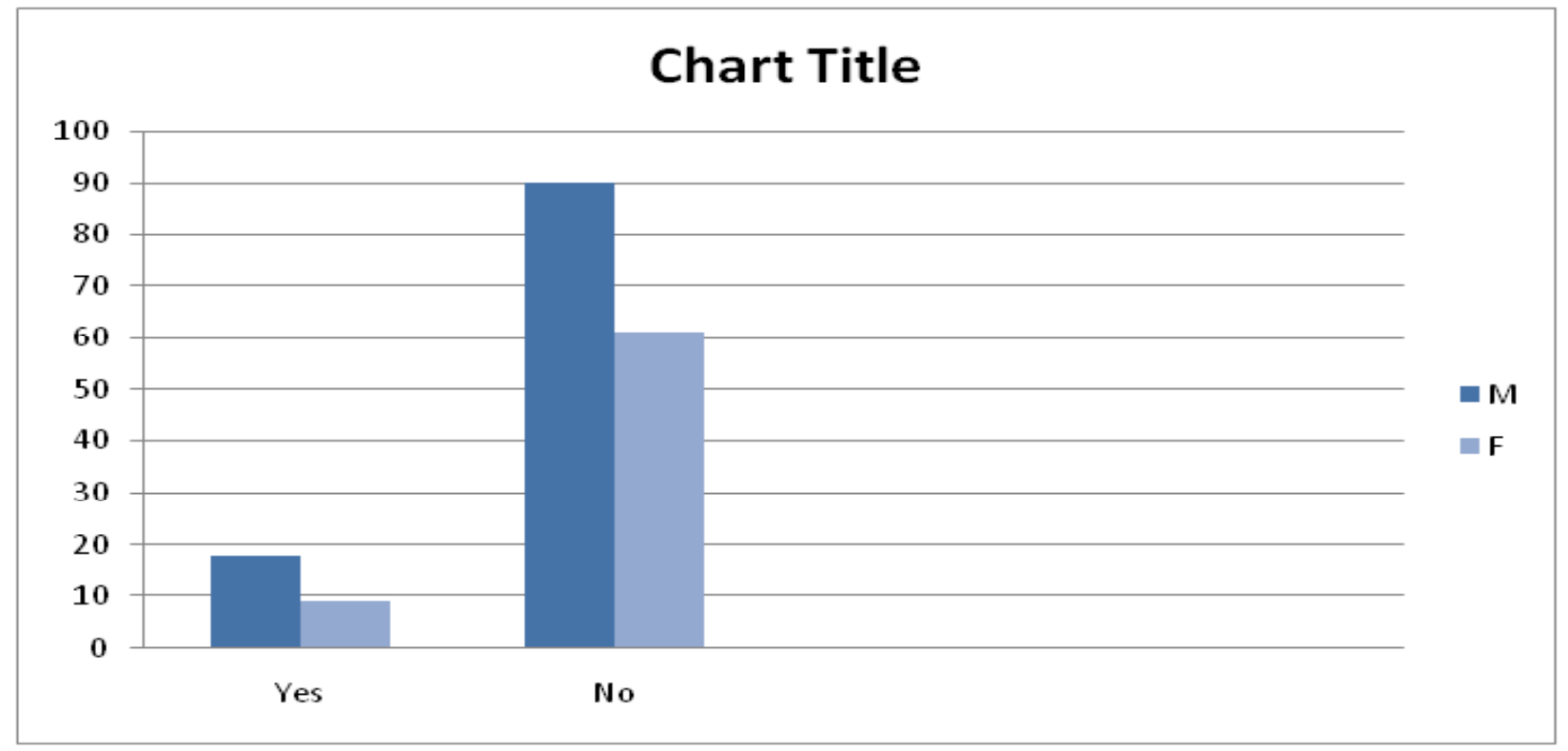

In the table below, it is represented the distribution of the patients according to age-group, associated with the graphical presentation:

\begin{tabular}{|c|c|c|c|}
\hline GROUP I & GROUP II & GROUP III & GROUP IV \\
\hline $0-<1$ month & $\geq 1$ month $-<4$ years old & $\begin{array}{c}\geq 4 \text { years old }-<6 \text { years } \\
\text { old }\end{array}$ & 17 \\
\hline 22 & 114 & $\mathbf{9 . 6 0 \%}$ & $\mathbf{1 3 . 5 6 \%}$ \\
\hline $\mathbf{1 2 . 4 3 \%}$ & $\mathbf{6 4 . 4 1} \%$ & & \\
\hline 177 & & & \\
\hline
\end{tabular}

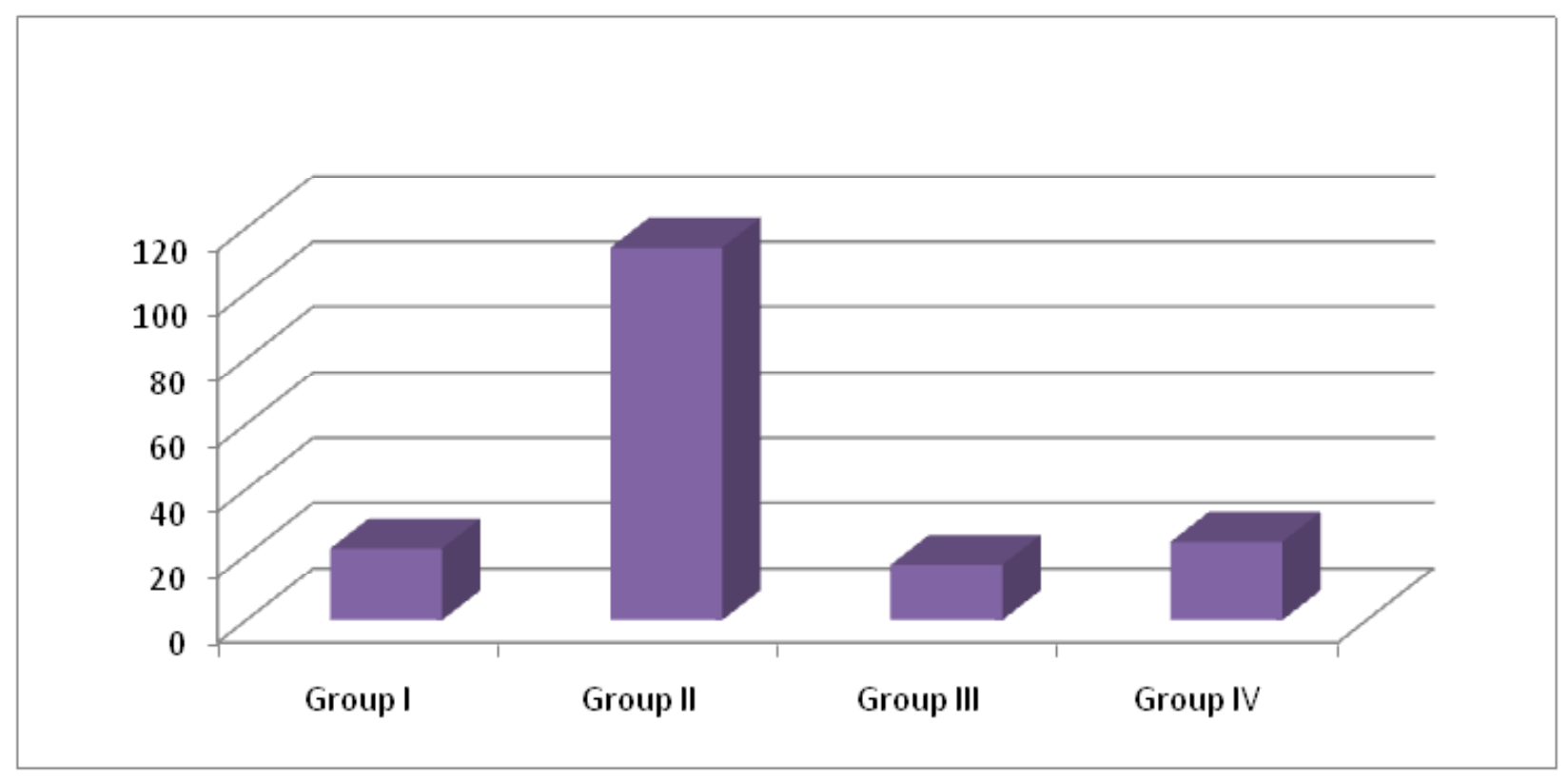




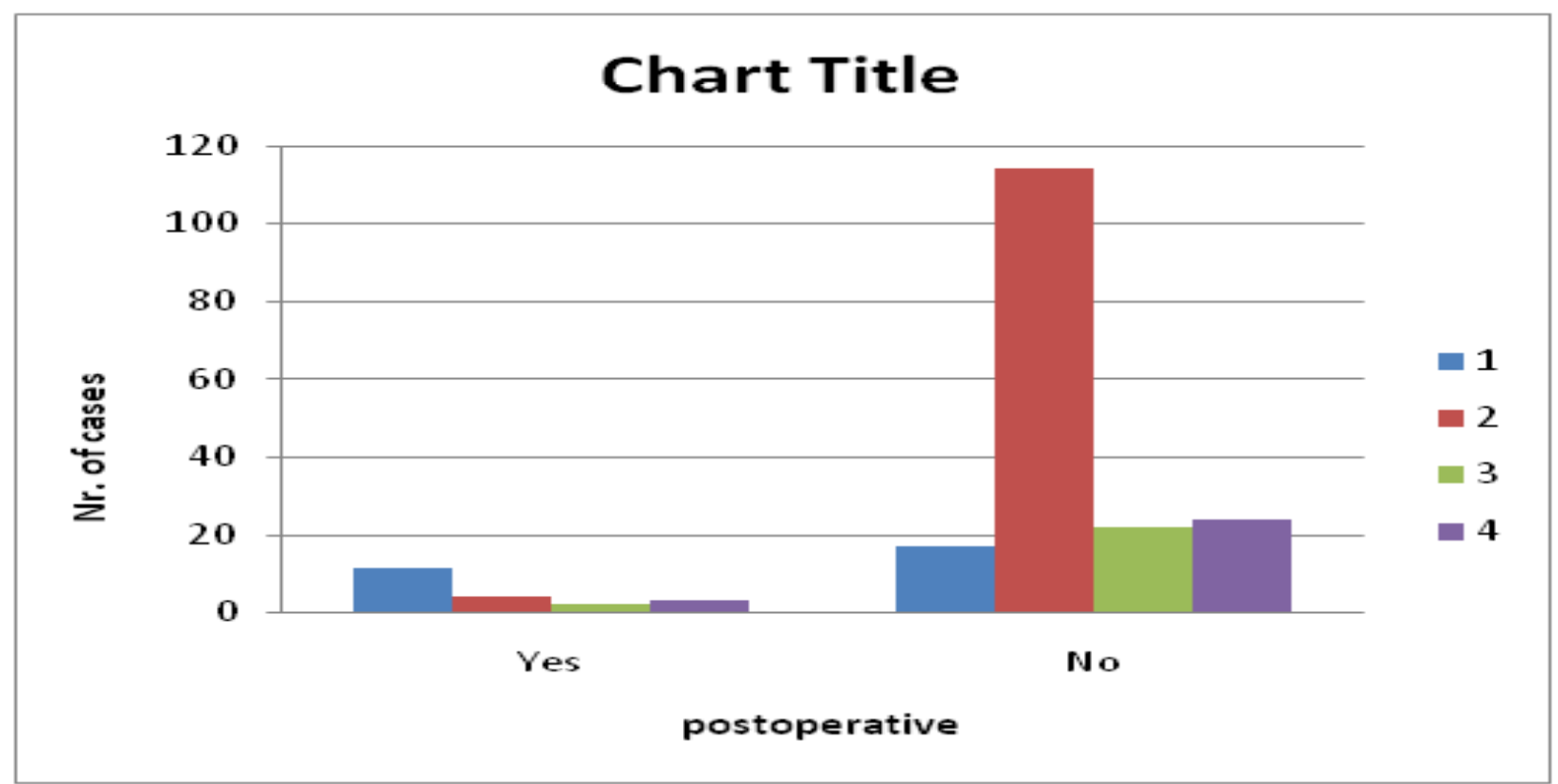

In relation to the pain level, the information about the surveyed patients is represented in the table and the graphic below:

\begin{tabular}{|c|c|c|c|c|c|c|c|}
\hline \multicolumn{3}{|c|}{ Postoperatorive } & \multicolumn{4}{c|}{ Non postoperative } \\
\hline Mild Pain & $\begin{array}{c}\text { Moderate } \\
\text { Pain }\end{array}$ & Intense Pain & $\begin{array}{c}\text { Maximum } \\
\text { Pain }\end{array}$ & Mild Pain & $\begin{array}{c}\text { Moderate } \\
\text { Pain }\end{array}$ & $\begin{array}{c}\text { Intense } \\
\text { Pain }\end{array}$ & $\begin{array}{c}\text { Maximum } \\
\text { Pain }\end{array}$ \\
\hline- & - & 10 & 11 & - & 9 & 87 & 60 \\
\hline- & - & $47.62 \%$ & $52.38 \%$ & - & $5.77 \%$ & $55.77 \%$ & $38.46 \%$ \\
\hline \multicolumn{7}{|c|}{21} & \multicolumn{5}{c|}{156} \\
\hline
\end{tabular}

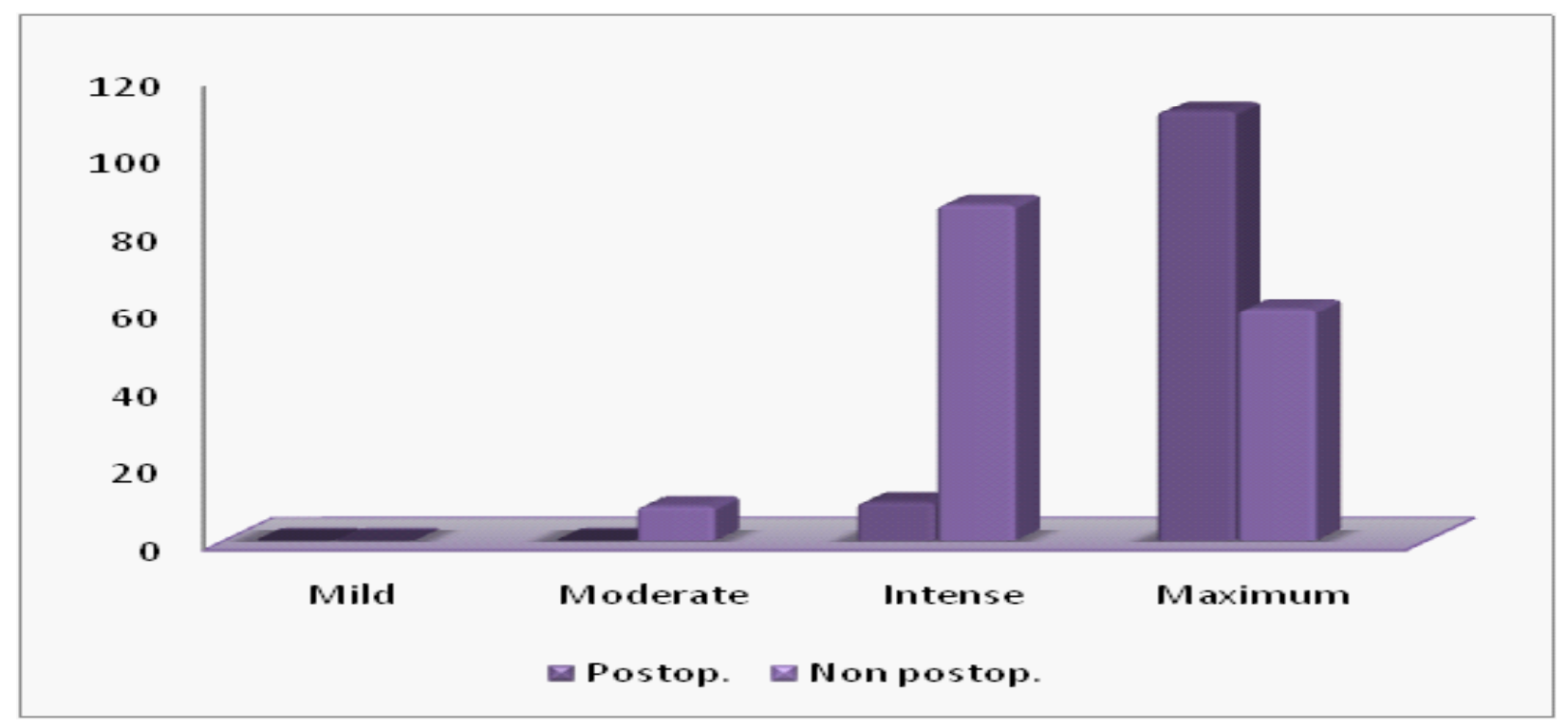




\section{Pediatric Patients and Pain}

Scoring averages of different scales according to age-groups are represented in the table below. Since there are used two different positions of VAS (horizontal and vertical), all the information below is given separated according to the different variants (in which VASH is the horizontal variant and VASV is the vertical one).

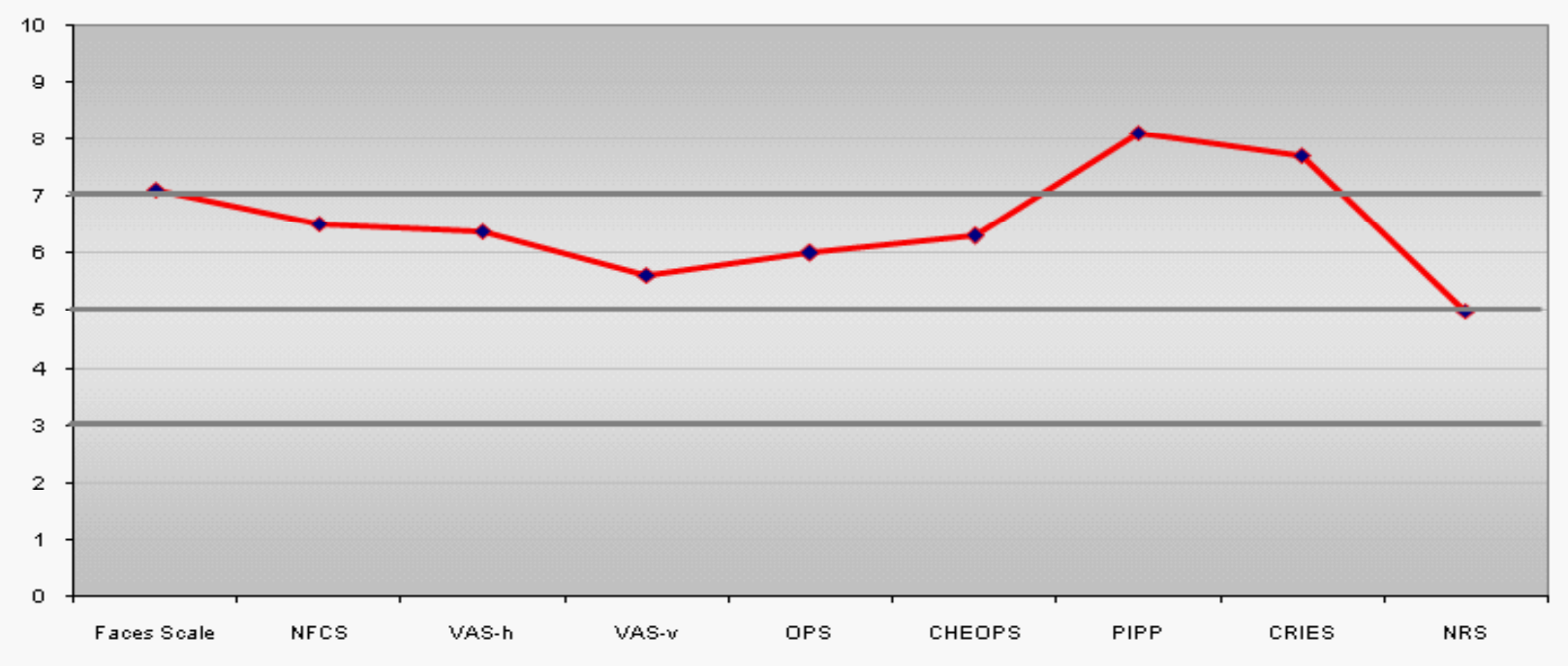

The scoring system for the Face Scale, NFCS, VAS, OPS, CRIES and NRS is 0-10.

While, for the CHEOPS (4-13) and PIPP (0-21) scales is applied the conversion of the average values to the $0-10$ system.

\section{Discussion}

According to the study's results, the percentage of postoperative patients with intense pain is $47.62 \%$ and with maximum pain is $52.38 \%$. There are $5.77 \%$ non-postoperative patients with moderate pain, $55.77 \%$ with intense pain and $38.46 \%$ with maximum pain. ${ }^{[6][14]}$ In conclusion, all postoperative patients and $94.23 \%$ of nonpostoperative children undergoing painful procedures experienced intense and maximum pain. ${ }^{[16][37][43]}$

The average of the obtained results using all the scales varies in that way to show intense or maximum pain levels, as well.

Most of the researchers claim that if we compare the pain levels between males and females, the first ones are lower, but it is not considered as statistically significant ( $p>0.05$ for all the scales). However, we should take in consideration the fact that the auto-evaluation is applied among a small sample (24 patients-13.56\%). ${ }^{[15]}$

The previous studies indicate different levels of scoring, using the visual analog scale (VAS) in two different orientations-horizontal and vertical. Researchers argue that there are inequalities because of the difficulties among the children's spatial orientation, from 0-10 years old. ${ }^{[20]}$

The NFCS and the Faces Scale are much more easily accessible by the nursing staff; while the multidimensional scales (OPS, CRIES, PIPP) were found more difficult to be used. ${ }^{[17][47]}$ This because of:

1. The considerable number of parameters to be assessed and saved in epidemiological files.

2. In many cases, there is not the required information about the levels of AP before and after the procedure.

3. Since there are required the reference values (the values of parameters before the surgical intervention or before the painful procedure), that could not be always documented. ${ }^{[34]}$ 
The presence of parents during the auto-evaluation has played an important role in children's maximal collaboration, increasing in this way the obtained data validity. ${ }^{[9][33][45]}$

\section{TREATMENT}

Pain treatment consists in providing a maximum pain reliefand a minimum of side effects. ${ }^{[10][35][42]}$ The multimodal analgesia is considered to be as the most suitable method, based on the synergistic effects of different analgesics, decreasing the necessity of using high doses and the incidence of adverse effects of them. ${ }^{[2][7][21]}$

\section{Analgesics}

Mild and moderate pain: could be used medicaments as paracetamol, NSAIDs (ibuprofen, naproxen, ketoprofen) and mild opioids (codeine, tramadol, dextropropoxyphene).

Average pain intensity: could be used opioids, accompanied with NSAIDs.

Intense pain: there are recommended major opioids (morphine, fentanyl, hydrocodone, oxycodone). NSAIDs could be used to increase the opioid's effects. ${ }^{[23][28][32]}$

Local anesthetics could be used as peridural and intrathecal administration.

There are two types of analgesics: minor and major, or opioids and non opioids. ${ }^{[30]}$

Acetaminophen (Paracetamol) is a minor analgesic that increases the effects of analgesia when it is used with another major analgesic. It is the most widely used analgesic among children for oral and rectal use. The optimal dose of acetaminophen it is not exactly defined, but usually it is used $10-15 \mathrm{mg} / \mathrm{k}$, oral use. High doses of acetaminophen used in children with serious infections are considered as an indication for hepatic insufficiency. Therefore, it is suggested to be used for short period of times ${ }^{[36]}$.

Ibuprofen is a non sterioid anti inflamator drug used mainly to treat the pain and temperature among children. ${ }^{[22]}$ It is suggested a $15 \mathrm{mg} / \mathrm{kg}$ dose for oral use to have an analgesic effect. However, for a repeated dose among 6 months to 12 years old children, it is suggested a dose of $10 \mathrm{mg} / \mathrm{kg}$, every $6 \mathrm{~h}$ oral use (maximum daily dose-40 $\mathrm{mg} / \mathrm{kg}) \cdot{ }^{[36]}$

Naproxen has a longer half-life than ibuprofen, therefore it could be used every $8-12 \mathrm{~h}$. It is not known any information about the effect on infants. The usual or normal dose is considered 5-10 mg/kg oral use, every 8-12 $\mathrm{h}$ (maximum daily dose-20 mg/kg). ${ }^{[22][36]}$

Opioid analgesics are used by the nursing staff under strict supervision of a doctor, because of the serious side effects, such as inhibition of respiration. ${ }^{[29]}$

Opioids are used to treat pain among patients of different ages. ${ }^{[22]}$ If the dosage is correct, the analgesic effects among children could be easily distinguished. ${ }^{[7][8]}$ There are different routes of administration available for opioids, including oral, intravenous, rectal, transmucosal or transdermal administration. ${ }^{[31]}$ It is important to avoid the intramuscular or subcutaneous route to pediatric patients. Most of opioids are available in liquid forms and could be easily applied to children with difficulties in managing the opioid pills. Recently, to manage neoplastic pain treatment among children, it is used Fentanyl Transdermal Patch or other forms of Fentanyl.

Sedatives are mostly used for their calming or sleep-inducting effect to reduce pain. ${ }^{\text {[25] }}$

The reasons why the pain could not be treated with opioids:

1. Side effects, such as respiratory depression.

2. Dependence.

3. Insufficient information possessed by the staff about these drugs. 
Skin stimulation relieves pain, as well. There are used different techniques such as pressure, massage, vibration, heat and cold therapy, oily treatment which are considered to be very effective and safe (Woolf \& Thompson, 1994). The activation of $A \beta$ big fibers and the inhibition of $A \delta$ and $C$ small fibers, which close the pain "gate", can cause sedative effects. ${ }^{[7][8]}$

\section{Massage}

Friction massage applied to the painful region could relax the muscles and decrease the tension. It is not recommended to the damaged skin since it could enlarge the damage. Skin irritation could be treated with menthol products, which contain methyl salicylate that could be absorbed, causing an analgesic effect in the affected area. Heat and cold therapy are use to decrease muscular pain (Lehmann and De Lateur). ${ }^{[37][39][42]}$ The immediate change of temperature, from heating to cold can cause analgesic effect that could last for hours. But, this is a method that can not be used within the first 24 hours to a traumatized area. Cold therapy reduces blood circulation causing positive effects, but preliminary we should take in consideration some advices about heat and cold therapy:

- To not use cold therapy to a hypovascular area

- To avoid extreme temperatures that can cause burn or freezing injuries

- To not apply heat therapy to a fresh wound because it might cause or increase bleeding

- To stop the application if the pain is increasing

\section{Controlateral stimulation}

In this case, the opposite areas are stimulated using pressure, massage, ice, heat and cold therapy or menthol to release pain (for example, when the right hand is damaged, we stimulate the left hand). It could be used when the affected areas are not exposed because of plasters, bandages or when the skin is irritated.

\section{Transcutaneous Electrical Nerve Stimulation (TENS)}

TENS by definition covers the complete range of transcutaneously applied currents, with low voltage, transmitted to the affected area through some electrodes. It produces analgesics effects through $A \beta$ fibers stimulation and A $\delta$ fibers inhibition.

Skin irritation could be a side effect caused by the electrode stickers. This could be avoided using hypoallergenic stickers, while redness could be avoided by cleaning the electrodes with soapy water. Contraindications of TENS include the application in eyes, forehead, mouth, neck. It is still not approved that TENS could perform safety during the very first months of pregnancy, butit is used to lower back part after it (McCaffery, 1979).[7][8]

\section{Recognition of Pain Relief Techniques}

\section{Entertainment}

It is really helpful for patients that are passing difficulties moments like intense pain, clothing difficulties, great physical disability. The visual entertainment includes reading, picture slideshows, listening to music, playing an instrument or playing with a pet etc. Pain relief is temporary, but if the patient likes what he is doing, the results will be positive.

\section{Roadmap for Managing Pain}

It is a technique in which patient is focused in pleasant, imaginative or visual situations, finding this as a good option to be relaxed. 
Hypnosis

Hypnosis depends on how much the consciousness of patients is influenced. This technique replaces the pain perception with another sensation (Syrjala, Cummings, and Donalds, 1992). Generally, around 20\% of hypnotized patients have successfully confronted pain (Syrjala, et.al.1992). But it is rarely applied because it is an expensive procedure, requires a lot of time to be performed and a qualified staff.

Relaxation, meditation, sedation are techniques that could control pain, as well.

\section{Biofeed back}

It is a method that trains patients to control certain bodily processes that normally happen involuntarily, such as heart rate, respiratory rate and muscle tone. Relaxation decreases pain, decreasing the anxiety as well, and increasing pain control.

Fear and death could accelerate pain levels. Sharing emotionally patient's experiences is as important as the treatment (Johnson, 1972; Johnson, Nail, Lauver, King, \& Keys, 1988). [24]

\section{CONCLUSIONS}

1. Assessment is the first step toward the appropriate postoperative and procedural acute pain management.

2. The correct usage of assessment scales, according to a standard protocol ensures to truthfully measure pain intensity, being the "key to success" for the necessary information used to create the pain treatment modalities.

\section{RECOMMENDATIONS}

1. A part of pediatric patients are not capable to give information referred to the experienced pain. Therefore, it is a staff obligation to improve their knowledge toward pain assessment.

2. It is suggested a continuous pain assessment in order to have an efficient treatment.

3. There should be avoided the abuse with painful procedures (to replace, if it is possible, the parenteral administration route of medicaments with the oral one). ${ }^{[40]}$

4. To choose the less painful procedure for application.

\section{RFERENCES}

1. Loeser JD, Treede RD. The Kyoto protocol of IASP Basic Pain Terminology. Pain. 2008;137:473-477. [PubMed]

2. Thienhaus O, Cole BE. Weiner RS. Pain management: a practical guide for clinicians. 6th ed. New York, NY: CRC Press; 2002. Classification of pain.

3. Ingelmo PM, Fumagalli R. Neuropathic pain in children. Minerva Anestesiologica. 2004;70:393-398. [PubMed]

4. Svendsen KB, et al. Breakthrough pain in malignant and non-malignant diseases: a review of prevalence, characteristics and mechanisms. European Journal of Pain. 2005;9:195-206. [PubMed]

5. Albertyn R, et al. Infant pain in developing countries; a South African perspective. In: Anand KJS, Stevens BJ, McGrath PJ, editors. Pain in neonates and infants. 3rd ed. Amsterdam: Elsevier; 2007. pp. 263-371. 
6. Gaughan DM, et al. The prevalence of pain in pediatric human immunodeficiency virus/acquired immunodeficiency syndrome as reported by participants in the Pediatric Late Outcomes Study (PACTG 219) Pediatrics. 2002;109:1144-1152. [PubMed]

7. Cancer pain relief and palliative care in children. Geneva: World HealthOrganization; 1998.

8. Okpala I, Tawil A. Management of pain in sickle-cell disease. Journal of Royal Society of Medicine. 2002;95:456-458. [PubMed]

9. Hofmann M, et al. Posttraumatic stress disorder in children affected by sickle-cell disease and their parents. American Journal of Hematology. 2007;82:171-172. [PubMed]

10. Benjamin L. Pain management in sickle cell disease: palliative care begins at birth? Hematology. 2008:466-474. [PubMed]

11. von Baeyer CL, Spagrud LJ. Systematic review of observational (behavioral) measures of pain for children and adolescents aged 3 to 18 years. Pain. 2007;127:140-150. [PubMed]

12. Pillai Riddell R, Racine N. Assessing pain in infancy: the caregiver context. PainResearch \& Management. 2009;14:27-32.[PubMed]

13. McGrath PJ, et al. Core outcome domains and measures for pediatric acute and chronic/recurrent pain clinical trials: PedIMMPACT recommendations. The Journal of Pain. 2008;9:771-783. [PubMed]

14. Cohen LL, et al. Evidence-based assessment of pediatric pain. Journal of Pediatric Psychology. 2008;33:939-955. [PubMed]

15. Huguet A, Stinson JN, McGrath PJ. Measurement of self-reported pain intensity in children and adolescents. Journal of Psychosomatic Research. 2010;68:329-336. [PubMed]

16. von Baeyer CL. Children's self-report of pain intensity: what we know, where we are headed. Pain Research \& Management. 2009;14:39-45. [PubMed]

17. Hicks CL, et al. The Faces Pain Scale - revised: toward a common metric in pediatric pain measurement. Pain. 2001;93:173-183. [PubMed]

18. Crellin D, et al. Analysis of the validation of existing behavioral pain and distress scales for use in the procedural setting. Pediatric Anesthesia. 2007;17:720-733. [PubMed]

19. Blount RL, Loiselle KA. Behavioural assessment of pediatric pain. Pain Research \& Management. 2009;14:47-52. [PubMed]

20. Stinson J, et al. Review of systematic reviews on acute procedural pain in children in the hospital setting. Acute Pain. 2008;10:105-106. [PubMed]

21. Ramelet AS, et al. Clinical validation of the Multidimensional Assessment of Pain Scale. Pediatric Anesthesia. 2007;17:1156-1165. [PubMed]

22. Franck LS, et al. Assessment of sickle cell pain in children and young adults using the adolescent pediatric pain tool. Journal of Pain and Symptom Management. 2002;23:114-120. [PubMed]

23. Vetter TR. A primer on health-related quality of life in chronic pain medicine. Anesthesia and Analgesia. 2007;104:703-718. [PubMed]

24. Palermo TM, et al. Evidence-based assessment of health-related quality of life and functional impairment in pediatric psychology. Journal of Pediatric Psychology. 2008;33:983-996. [PMC free article] [PubMed] 


\section{Pediatric Patients and Pain}

25. Long AC, Krishnamurthy V, Palermo TM. Sleep disturbances in school-age children with chronic pain. Journal of Pediatric Psychology. 2008;33:258-268. [PMC free article] [PubMed]

26. Blount RL, et al. Evidence-based assessment of coping and stress in pediatricpsychology. Journal of Pediatric Psychology. 2008;33:1021-1045. [PMC free article] [PubMed]

27. Albertyn R, etal. Challenges associated with paediatric pain management in Sub SaharanAfrica. International Journal of Surgery. 2009;7:91-93. [PubMed]

28. WHO Expert Committee on the Selection and Use of Essential Medicines. WHO model list of essential medicines for children: 2nd list (updated) March 2010. Geneva: World Health Organization; 2010.

29. Anand KJ, et al. Tolerance and withdrawal from prolonged opioid use in critically ill children. Pediatrics. 2010;125:1208-1225. [PMC free article] [PubMed]

30. Berde CB, Sethna NF. Analgesics for the treatment of pain in children. New England Journal of Medicine. 2002;347:1542. [PubMed]

31. Challapalli V, et al. Systemic administration of local anesthetic agents to relieve neuropathic pain. Cochrane Database of Systematic Reviews. 2005;(4):CD003345. [PubMed]

32. De Lima L, et al. Potent analgesics are more expensive for patients in developing countries: a comparative study. Journal of Pain \& Palliative Care Pharmacotherapy. 2004;18:59-70. [PubMed]

33. Ho IK, et al. Healthcare utilization and indirect burden among families of pediatric patients with chronic pain. Journal of Musculoskeletal Pain. 2008;16:155-164

34. Scoping document for the WHO treatment guidelines for chronic pain in children. Geneva: World Health Organization; 2008

35. International Narcotics Control Board. The report of the International Narcotics Control Board for 2008. New York, NY: United Nations; 2009

36. Merskey H, Albe-Fessard DG, Bonica JJ, et al. Pain terms: a list with definitions and notes on usage: recommended by the IASP Subcommittee on Taxonomy. Pain 1979;6:249-52

37. Annequin D., Canaoui P., Cloup C. Enquête multicentrique sur la douleur en réanimation pédiatrique In Journées Parisiennes de Pédiatrie, Paris, Flammarion Médecine Sciences, 1991:89-94

38. Mc Caffery M, Pasero C, eds. Pain: Clinical Manual, 2nd ed. St. Louis, MO:Mosby 1999.

39. Evaluation et stratégie de prise en charge de la douleur aiguw en ambulatoire chez l'enfant de 1 mois à 15 ans. www.anaes.fr

40. Stevens B, Taddio A, Ohlsson A, Einarson T. The efficacy of sucrose for relieving procedural pain in neonates: a systematic review and meta-analysis. Acta Paediatr 1997;86:837-42.

41. Stevens B, Johnston C, Petryshen P, Taddio A. Premature Infant Pain Profile: development and initial validation. Clin J Pain 1996;12:13-22

42. Am. Acad. Pediatrics La prévention et la prise en charge de la douleur et du stress chez le nouveau-né Pediatrics $2000 ; 105: 454-461$

43. Goddard JM, Pickup SE. Postoperative pain in children. Anaesthesia 1996;51:588-90

44. Fournier-Charrière E, Dommergues J. La douleur chez l'enfant : aspects spécifiques. La Revue du Praticien 1994 ; 44 :1925-1931.

American Research Journal of Pediatrics

Page 36 


\section{Pediatric Patients and Pain}

45. Gauvain-Piquard A. La décision de traiter un enfant pour sa douleur In : Cook J., Tursz A. in "L'enfant et la douleur, famille et soignants", Paris, Ed. Syros, 185, 1998:105-113

46. Hicks CL, Von Baeyer C, Spafford PA, Van Korlaar I, Goodenough B. The Faces Pain Scale revised: toward a common metric in pediatric pain measurement. Pain 2001; 93:173-183.

47. Ohnhaus EE \& Adler R: Methodological problem in measurement of Pain: A Comparison Between VRS \& VAS. Pain : 379,1975

48. Pichard Leandri E. Evaluation de la douleur chez l'enfant. Rev Int Pediatr 1997 ; 28 : 20-25.

Citation: Pistulli E, Krasniqi F, Neçaj L, "Pediatric Patients and Pain". American Research Journal of Pediatrics; 1(1): 25-37.

Copyright (c) Pistulli E, Krasniqi F, Neçaj L. This is an open access article distributed under the Creative Commons Attribution License, which permits unrestricted use, distribution, and reproduction in any medium, provided the original work is properly cited. 